some extent policies in development of those suggested in "Britain's Industrial Future" four years ago, frankly recognises these changes and accepts the necessity of adapting the structure and policies of society to meet the problems which arise. The authors of these papers have no quarrel with science as such, but rather recognise that science must play an important part in the planning and reconstruction which are essential for the continuance of our civilisation-that indeed modern science rightly applied could raise the standard of living to heights previously unknown and supply the material resources for a more abundant life for all. This is evident in their emphasis on science as a first major factor in agricultural policy, and their conviction that development of scientific research, its application to farming and improved marketing, are essential to the future prosperity of British agriculture.

The value of international industrial agreements is recognised, while imperial industrial agreements including imperial research are suggested as a line of promising development. While repudiating a policy of tariffs, this Liberal group advocates a system of national planned development comprising a national industrial commission with industrial and agricultural councils not unlike the Industrial Parliament visualised by Capt. Harold Macmillan in his scheme of creative protection. They argue further, however, that the State should also foster industry by keeping the demands for its products at a high economic level through well-planned social service and a constructive policy of national development. The perils presented by economic nationalism are not overlooked, and a paper on the international framework surveys the various problems such as disarmament, minorities, treaty revision, war debts, population, and migration, in which international co-operation and understanding are essential if progress is to be made. Even those scientific workers who, on the question of tariffs, differ most widely from the authors of these papers, should find much that is interesting and stimulating in their frank and virile statement of policy in the light of the actual facts of the present situation.

\section{World-wide Telephony}

At the International Electrical Congress recently held in Paris, several important papers were read on telephony. B. Gherardi and F. B. Jewett discussed 'world telephony'. The history of the subject illustrates how great discoveries occur at various intervals of time. Each of them causes a revolution in practice and between the intervals the process of applying the new inventions goes on continuously in the economic field. Such epoch-making discoveries were the invention of the thermionic tube, the perm. alloy series of nickel-iron alloys, and the discovery of paragutta. The use of paragutta has reduced the transmission losses to one-thirtieth of their former value. Many difficulties remain for engineers to overcome. For telephony between North America and Europe, ' long' radio waves are most suitable, but there is the fundamental restriction that there are in practice only twenty 'ways' available owing to the limited breadth of the band of frequencies that can be utilised. With 'short' wave-lengths, the best wave-length to use depends on the hour of the day and the season of the year. Hence three wave-lengths are usually assigned to each circuit, and this limits the number of ways. Short-wave transmission is still in the first stage of its evolution; interruptions due to the vanishing of signals and to magnetic storms occur not infrequently, especially when the waves go through polar regions. The difference in local time between many large towns is a great inconvenience. There may be no overlapping in time between their working days. The language difficulty, although of less importance, is still a hindrance to progress. Many conversations are held between speakers in a language which neither knows well. In this case it is necessary that the clarity of the transmission be much better than when each is speaking his own tongue. Technical progress has now made possible communication between countries and continents. Whether this will be a boon to humanity or not depends on the nature of these communications.

\section{Prof. Piccard's Ascent into the Stratosphere}

ON Aug. 10, Prof. A. Piccard, of the University of Brussels, accompanied by M. Max Cosyns, ascended at about 5 A.M. from Dubendorf Aerodrome, near Zurich, in a specially constructed balloon. He rose to a height of 16,700 metres (about $10 \frac{1}{2}$ miles), thus penetrating well into the stratosphere, and, after a twelve hours' flight, landed at Cavallaro di Monzambano, which is about ten miles south of Lake Garda. Among the equipment of the balloon was a wireless set, by means of which Prof. Piccard sent messages to surface observers. It will be recalled that this was Prof. Piccard's second ascent, his first having been on May 27, 1931, when he reached a height of $9 \frac{3}{4}$ miles. As was to be expected, the aeronauts suffered considerable discomfort. The greatest trouble was the intense cold encountered in the stratosphere. Prof. Piccard states that he has made a number of observations which he hopes will prove of great value, but of any scientific results it is too early to speak. During his previous flight, Prof. Piccard had hoped to obtain evidence of the cosmic rays under more favourable conditions, and any contributions that he may be able to make in this field, from this flight, will be awaited with interest. Meteorologists look forward to the announcement of Prof. Piccard's results, especially if he has been able to make any observations on the composition of the atmosphere within the stratosphere; for, in spite of the observations already made by self-recording instruments on unmanned balloons, very little is actually known at present about this region.

\section{Trans-Atlantic Flight from East to West}

AFTER waiting for some days at Portmarnock Strand, Co. Dublin, for suitable weather conditions, Mr. J. A. Mollison started on Aug. 18 at 11.30 A.M. on a solo flight across the Atlantic. His original intention was to strike the coast of North America, fly on to New York, and, after a short rest, to fly back across the Atlantic, thus making a round trip in about

No. 3278 , Vor. 130] 
three days. After thirty hours of flying, Mr. Mollison landed successfully at Pennfield Ridge, New Brunswick; it appears that he had sufficient fuel to go on, but was obliged by fatigue to come down. He was flying a Puss Moth aeroplane with a 120 h.p. Gipsy engine, such as is supplied to private owners, with the exception that the passenger seat has been replaced by petrol tanks. It is stated in the Daily Mirror that the direct costs of the flight were only $£ 106 s$. $3 d$. for petrol and 15s. for oil. Mr. Mollison is the first to cross the Atlantic from east to west in a solo machine, which, incidentally, is the smallest to accomplish the crossing. The flight is a noteworthy tribute to the endurance of both man and machine.

\section{Late Bronze Age Settlement in Shetland}

A LATE bronze age settlement of considerable extent has been brought to light by excavation under the Office of Works at Sumburgh, at the southern end of the Shetlands. Previous excavation had revealed an iron age site, dating from about the beginning of the Christian era. During the present season, according to a correspondent in the Times of Aug. 19, six weeks' excavation has completely cleared one dwelling, partially cleared two more, and indicated the existence of others. The completely excavated dwelling shows evidence of four occupations, of which the third, as is shown by broken clay moulds, was much taken up with bronze-casting. It is $31 \mathrm{ft}$. in length, has an original and a secondary entrance, and three chambers with four lesser chambers opening out of them. The walls are three feet high and are built of selected pebbles from the shore, neatly fitted and without filling, except in the lower courses, where clay has been used to keep out the damp. Slate was much in use for tools. Both slate and stone implements show types not in use on the mainland. Of the partially excavated houses, the walls of one pass under those of the excavated house, and are therefore older. Slate was in use here. Though pottery is scarce, the ornament on one sherd gives a bronze age date. The second partially excavated dwelling is older again; but a sword and pottery of the type of Heathery Burn Cave, Co. Durham, still point to the late bronze age. Although the full extent of the settlement is not yet revealed, the existence of several other dwellings has been noted. When excavation is complete, the settlement will probably prove the most elaborate in plan of any known bronze age dwelling-place in Britain.

\section{Roman Villa at Southwick}

IT is announced that the Roman villa at Southwick has been given to the Sussex Archæological Trust with the object of ensuring its preservation. The villa is one of a chain of Romano-British buildings, probably farms, on a four-mile belt of fertile land south of the Downs, the others being at Kingston, Portslade, West Blatchington, and Brighton. The site has been excavated by Mr. S. E. Winbolt and others, with the aid of the Sussex Archæological Society. It was found to consist of a triangular block of buildings enclosing a courtyard approximately $200 \mathrm{ft}$. by $130 \mathrm{ft}$. The chief rooms are on the north side, where they are protected from the wind by the Downs; while verandahs on the sunny side face the sea. The buildings are solidly constructed, with walls $2 \mathrm{ft}$. and $3 \mathrm{ft}$. thick, and consist of rubble cores faced with flint. The site is at present unfenced; but as soon as funds have been raised, the northern portion containing the main buildings, which unfortunately is separated from the southern by the new road, will be fenced and reconditioned to enable the public to be admitted at a small fee. The Trust, to which the site has been handed over, was formed in connexion with the Sussex Archæological Society for the preservation of the ancient monuments of Sussex, and already holds in trust Lewes Castle, Wilmington Priory, the Long Man of Wilmington, the Marlipins at Shoreham, and Oldland Mill at Keymer.

\section{Earliest known Pueblo Dating}

DR. Frank H. RoBerts, Jr., who is in charge of an expedition of the Bureau of American Ethnology excavating Pueblo settlements on a site near Allentown, Arizona, is reported by Science Service, of Washington, D.C., to have obtained from one of the houses he has excavated beams which, according to the tree-ring chronology, were cut in the year A.D. 797. This is the oldest date for which evidence has been found in Pueblo ruins in the south-western United States. The dwelling was a pit-house, built largely underground, with an entrance through the roof. It had been destroyed by fire, the inhabitants leaving most of their belongings behind them, including much pottery. The oldest dates previously established by means of the tree-ring calendar elaborated by Prof. Douglass were A.D. 919 from a beam at Pueblo Bonito, and A.D. 861 from a piece of timber at Una Vida. Both these sites are situated in New Mexico.

\section{Electric Tramcar Systems}

AвоUт the beginning of the present century many local authorities undertook the installation of electric tramway systems in cities and towns, and many workers reaped the benefit of this system of transport. The coming of the petrol bus has led many to think that in a few years' time tramways will disappear. Their immobility often causes tramway congestion, and intending passengers have to cross a stream of traffic in order to board them, unless this stream be temporarily arrested. When one sees the great part played by tramcars in cities like London, Glasgow, and Manchester, and in many cities abroad, where tramcars with two or three trailers attached are continually going through crowded streets, it is obvious that it will be many years before they are obsolete. The large number of tramcars in Austria which were installed more than twenty years ago on the supposition that vehicles would always drive on the lefthand side of the road has led to difficulties in certain districts where one must now drive on the right-hand side. The cost of obtaining uniformity by altering the tramway lines in Austria is prohibitive at the present time. Just as in the case of weights and measures, what has been done in the past makes it 